\title{
A Study on the Control of Attached Algae by Installing the Drainage Cover Device for the Final Sedimentation of Sewage Treatment Plant
}

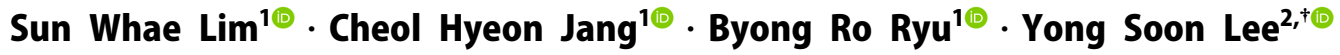 \\ 'Department of Environment Engineering, Hanbat National University \\ ${ }^{2}$ Department of Environmental Engineering, Daejeon University
}

(Received December 3, 2020; Revised April 19, 2021; Accepted April 20, 2021)

Objectives: Adherent algae which are generated in the final sedimentation weir of the sewage treatment plant and the drainage channel, affect the quality of the final effluent water, and it has bad aesthetic effect due to fomation of flcok floating in the sedimentation tank. Therefore, the purpose of this study is prevention of the growth of adherent algae in advance by installing circular cover on the final sedimentation weir and drainage channels.

Methods: In this study, we compared the growth pattern of adhered algae on weir and drainage channels before and after installation of circular cover at the final sedimentation weir and drainage channel of the sewage treatment plant. In addition, to identity species of attached algaem microscopic observation was applied, and ch-a concentration was analyzed to confirm the quality of the final effluent water.

Results and Discussion: Then, we compared the results before and after installation of cover to check adhesion status of algae on the surface of final sedimentation drain. In case without cover, it was confirmed by observing the growth of attached algae under normal condition with air and photosynthetic reaction, and in case with cover, it was compared with opening after a certain period of time after installation of the drainage cover. As a result of the comparison, it was confirmed that a lot of attached algae occurred in the sedimentary weir and the drain. From the above results, the occurrence of final sedimentation algae is not only affected by the material and season of the drainage, but also after the formation a cluster by algae that have strong adhesion force, and then the microbial species contained in the effluent build secondary attachment and forms colony.

Conclusions: In order to prevent the growth of adherent algae, a method of suppression of the growth of adherent algae by inhibition of photosynthesis was studied by installing a cover device on the weir and drain channels. As a result of installing a cover (34,000 thousand won) and reviewing economic feasibility, it can be recovered in 2.6 years, and stainless steel was selected in the view of mechanical stability and facility aging. The final sedimentation water quality increased $99.8 \%$ of Ch-a concentration treatment efficiency and $15 \%$ of SS sedimentation efficiency by installing a cover.

Keywords : Adherent Algae, Cover Device

The Korean text of this paper can be translated into multiple languages on the website of http://jksee.or.kr through Google Translator. 


\title{
연구논문
}

\section{하수처리장 최종침전지 배수로 덮개장치 설치로 부착조류제어에 관한 연구}

\author{
임선회 ${ }^{1 \odot} \cdot$ 장철현 $^{1 \oplus} \cdot$ 유병로 $^{1 \odot} \cdot$ 이용순 $^{2,+\odot}$ \\ ${ }^{1}$ 한밭대학교 환경공학과 \\ ${ }^{2}$ 대전대학교 환경공학과
}

목적: 하수처리장 최종침전지 웨어 및 배수로에 부착조류가 발생되어 최종 방류수 수질에 영향을 주며 침전지에 부유성으로 떠있어 미관상 좋지 않은 영향을 주고 있다. 그래서 최종침전지 웨어 및 배수로에 원형 덮개를 설치하 여 부착성 조류가 성장 발생하는 것을 사전에 방지하는 것을 목적으로 하였다.

방법: 본 연구에서는 하수처리장 최종침전지 웨어 및 배수로에 원형 덮개를 설치하고, 설치 전·후 웨어 및 배수로 에 성장 발생한 부착조류 상태를 확인하였다. 그리고 부착조류의 종이 무엇인지 확인하기 위해 현미경을 통해 관 찰하였으며, 최종방류수 수질을 확인하고자 ch-a 농도를 분석하였다.

결과 및 토의: 최종침전지 배수로 부착조류의 부착상태를 확인하기 위해 덮개 설치 전·후를 비교하였다. 덮개 설치 전은 광합성 작용하에서 자연중에 부착조류의 성장과정을 지켜보면서 확인하였고, 부착 후는 배수로 덮개 설치 후 일정시간 지난 후에 개방하여 비교하였다. 비교한 결과 부착조류가 침전지 웨어 및 배수로에 많이 발생한 것을 확 인할 수 있었다. 위의 결과로 볼 때 최종침전지 부착조류 발생은 배수로의 재질(스테인리스, 에폭시, 알루미늄 등) 및 계절(여름철 광합성 작용)에 따라 달라질 수 있으며 부착성이 강한 조류가 군집을 형성한 후 유출수에 함유되어 있는 미생물 종 등이 2차적으로 부착 성장하여 군집을 형성하였을 것으로 사료된다.

결론 : 부착조류가 성장하는 것을 방지하기 위해 웨어 및 배수로에 덮개장치를 설치하여 광합성작용에 의한 부착조 류 증식을 억제하는 방법을 연구하였다. 덮개 설치 비용(34,000천원)을 경제성 검토한 결과 2.6년이면 회수가 가능 하며 안전성 및 시설 노후화를 고려하여 스테인리스 재질을 사용하였다. 최종침전지 수질관리는 덮개를 설치함으 로써 ch-a 농도 처리효율 $99.8 \%$ 및 SS 침전효율 $15 \%$ 향상되었다.

주제어 : 부착조류, 덮개장치

\section{1. 서론}

일반적으로 가정이나 공장 등에서 발생되는 생활폐수나 공 장폐수, 축산폐수 등과 같은 오염된 물은 별도의 처리 과정을 거쳐 재활용하거나 강이나 바다로 방류하는 것이 하수처리장 의 역할이다.

옥천환경사업소의 경우 인구 52,000 명, 평균 유입량이 $24,000 \mathrm{~m}^{3} / \mathrm{d}$ 이다. 유입수의 평균 수질농도는 Fig. 1 에 나타내 었고, 방류수 수질기준에 적합하고 하수처리 효율이 우수하여 대청호 상류 수질보전에 기여하고 있다. 그러나 최종침전지 웨어 및 배수로에서 햇빛에 의한 광합성 작용으로 부착조류 (attached algae)가 자생적으로 발생하여 다양한 조류들이 부 착조류 군집을 형성한다. ${ }^{1}$ 이들 부착조류들은 일정기간 성장
한 후에 구조물에서 탈리되어 침전지 수면에 부유하면서 조류 스컴을 형성하며, 다음 공정으로 유출되어 최종 방류수 수질 에 영향을 미치게 된다.

부착조류 발생은 매년 되풀이 되는 현상으로 하수처리장의 경우 인력 및 예산을 투입하여 주기적으로 청소를 해야 하는 문제점 및 위험성을 안고 있다. ${ }^{2)}$ 또한 청소를 한 후 2 주 정도 지나면 연녹색의 부착조류가 다시 발생하며, 부착조류가 육안 으로 확인된 후에는 급격히 성장한다. ${ }^{3)}$ 정수처리시설에서는 조류가 과다하게 발생하는 시기에 주로 전염소나 오존농도를 강화하거나 분말활성탄을 투입하는 등의 방법)으로 조류의 문제를 대처해 왔다. 염소나 오존 산화처리는 조류세포의 제 거에는 효과적이나 세포내의 독성 유기물이 수중으로 유출되 는 문제와 소독 부산물이 생성되어 인체에 악영향을 끼칠 수 


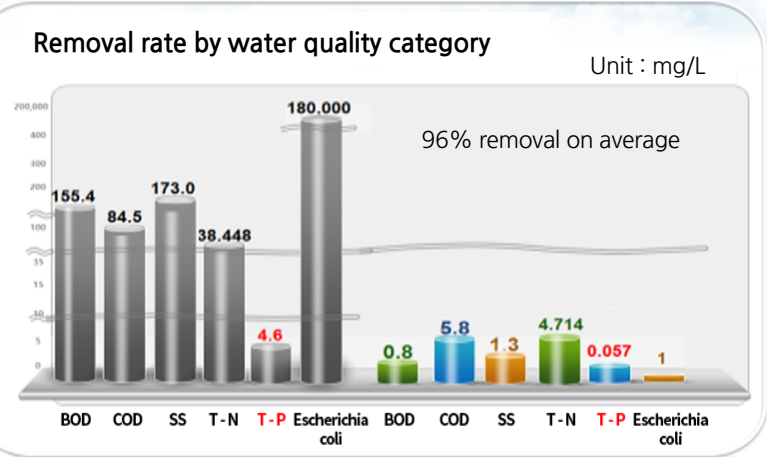

Fig. 1. Average quality of inflow and effulent of ogcheon sewage treatment plant (2019).

있다. ${ }^{5)}$ 현재 조류 제어를 위해 하수처리장은 침전지와 배수로 를 에폭시나 스테인리스강, 알루미늄 재질을 사용하여 침전지 배수로를 제작 설치하기도 하며, 브러쉬나 고압살수를 이용하 여 제거하고 있는 실정이다.

\section{2. 재료 및 방법}

\section{1. 클로로필 실험}

ch-a는 식물의 녹색 줄기 속에 함유된 녹색의 색소이며, 녹 색 줄기 중에서 태양 광선과 물, 탄산가스로 광합성에 의하여 녹말을 합성하는 반응의 매체가 된다. 엽록소는 광합성을 실 시하면 다량의 산소가 발생된다. 녹색식물에서는 하루 중 엽 록소의 약 $10 \%$ 가 대사 경로에 의해 새로 합성된다. 자연계에 는 많은 종류의 엽록소 및 유사물질이 분포하고 있다. 엽록소 는 유기용매 속에서 강한 형광을 발하는데, 엽록소를 함유하 는 세포에서 발하는 형광은 이것보다 훨씬 약하다. 클로로필 $\mathrm{a}, \mathrm{b}, \mathrm{c}, \mathrm{d}, \mathrm{e}$ 등이 있으며, ch-a는 박테리아를 제외한 독립 영양 식물의 모두에 분포하고, $a$ 와 $b$ 는 모두 고등식물, 녹조에 포함 되고 있다.

옥천환경사업소 최종침전지 웨어 및 배수로에 있는 부착조 류의 ch-a 농도를 알아보기 위해 실험을 하였다. 클로로필 실
험 방법(수질오염공정시험법)은 다음과 같다. 시료 $1,000 \mathrm{~mL}$ 를 유리섬유여과지로 여과한다. 여과한 여과지와 아세톤(9+1) 적당량 $(5 \sim 10 \mathrm{~mL})$ 을 조직마쇄기에 함께 넣고 마쇄한다. 마쇄 한 시료를 마개 있는 원심분리관에 넣고 밀봉하여 $4^{\circ} \mathrm{C}$ 어두운 곳에서 하룻밤을 보관한다. $500 \mathrm{~g}$ 시료를 원심분리기로 20 분 간 원심분리 한 후 분리한 시료의 상층액 시료를 정확히 채취 한다. 전처리한 시료 적당량을 취하여 층장 $10 \mathrm{~mm}$ 흡수셀에 옮겨 흡광광도계를 이용하여 측정한다. 아세톤(9+1)을 대조 용액(ZERO)으로 하여 시료를 각각 $663 \mathrm{~nm}, 645 \mathrm{~nm}, 630 \mathrm{~nm}$ 및 $750 \mathrm{~nm}$ 에서 시료용액의 흡광도를 측정한다. 각각 파장에 서 측정한 시료의 흡광도를 Fig.2의 식에 대입하여 ch-a의 농 도를 구한다. Fig.2의 사진은 ch-a의 농도를 구하는데 사용된 흡광광도계이다.

\section{2. 조류 종}

조류는 서식 형태에 따라서 부유성과 저서성으로 나뉘며, 저서성에는 수역의 바닥 침전물 등에 서식, 수생식물에 부착, 돌에 부착, 동물에 부착하는 것 등이 있다. 섬모나 편모가 없 는 규조류는 종에 따라서 단단한 표면의 활주운동에 의해서 움직인다. 활주운동은 물리, 화화적 반응에 의해서 점액성 물 질의 분비로 인해 일어나거나 변형된 아메바 운동에 의해 일 어난다.

호소의 플랑크톤, 하상의 부착조류, 완속여과지의 여과막을 구성하는 생물로 물의 정화에 중요한 역할을 하고 있으나, 대 량 번식할 경우에는 여과지 폐쇄를 일으키거나, 물에서 비린 내 등을 발생시킨다. 세포벽이 단단하여 쉽게 부서지지 않아 어류나 수서곤충 등의 위장에서도 세포 형태가 원형 그대로 존재하는 경우가 많다.

\subsection{1. 규조류}

Fig. 3은 전자현미경으으로 관찰한 규조류의 대표적인 종인 Melosira는 세포의 폭은 8 35 $\mu \mathrm{m}$, 길이는 9 13 $\mu \mathrm{m}$ 정도의 원통형 세포이며, 조밀하게 직선상으로 연결된 사상의 군체를

$$
\begin{aligned}
& \text { ch-a }\left(\mathrm{mg} / \mathrm{m}^{3}\right)=\frac{\left(11.64 X_{1}-2.16 X_{2}+0.10 X_{3}\right) \times V_{1}}{V_{2}} \\
& \mathrm{X}_{1}: \text { OD663 - OD750 } \quad \mathrm{X}_{2}: \text { OD645 - OD750 } \\
& \mathrm{X}_{3}: \text { OD630 - OD750 OD : Optical density } \\
& \mathrm{V}_{1}=\text { Supernatant sample volume }(\mathrm{mL}) \\
& \mathrm{V}_{2}=\text { Filtration volume }(\mathrm{L})
\end{aligned}
$$

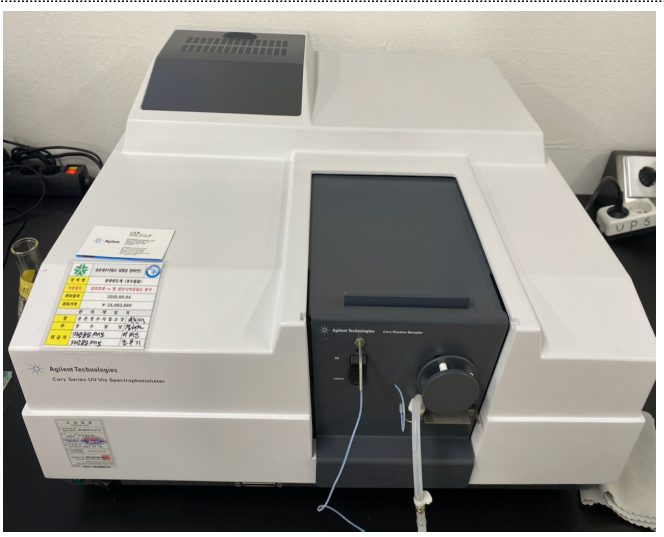

Fig. 2. ch-a Analysis with Absorption Photometer. 


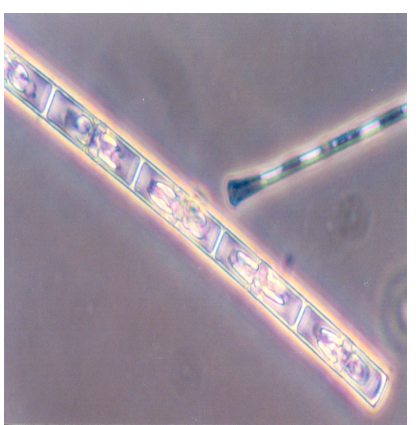

(a) Melosira

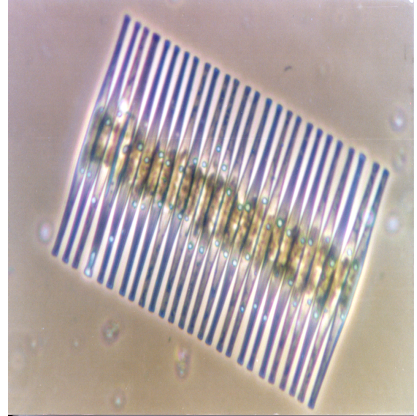

(b) Fragilaria

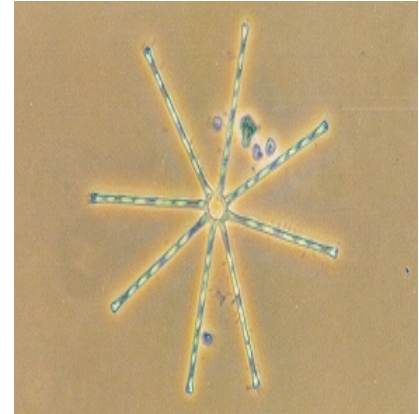

(c) Asterionella

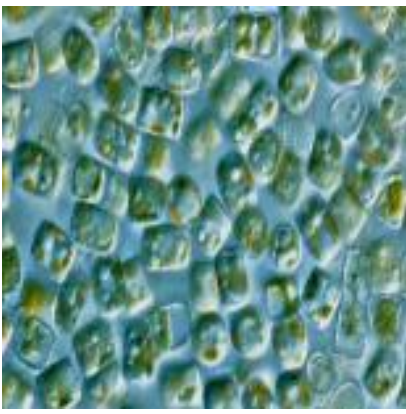

(d) Cyclotella

Fig. 3. Microscopic images of diatoms.

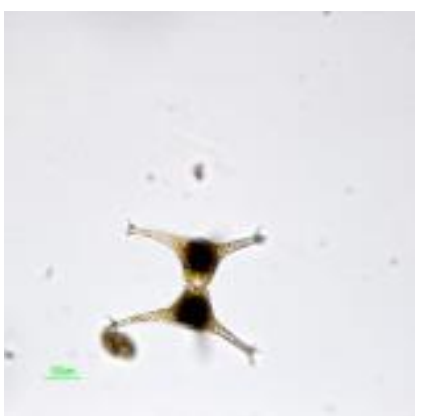

(a) Staurastuum

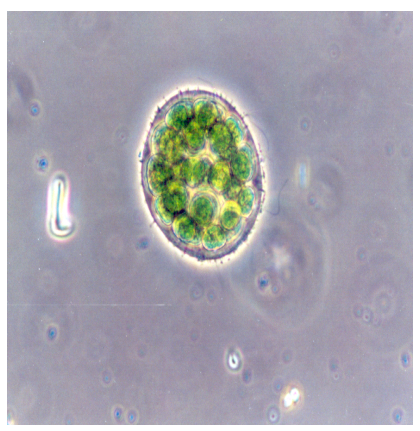

(b) Eudorina

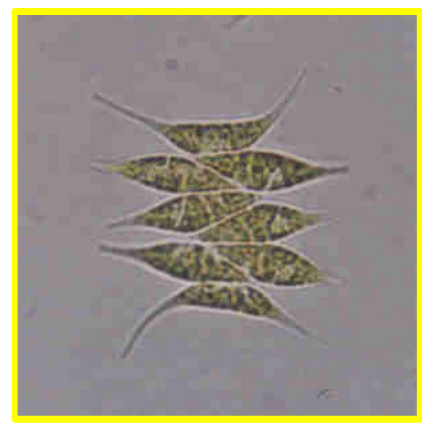

(c) Scenedesmus

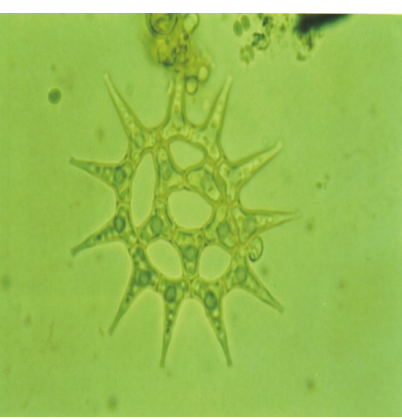

(d) Pediastrum

Fig. 4. Microscopic images of green algae.

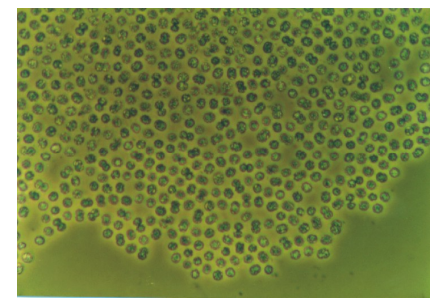

(a) Microcystis

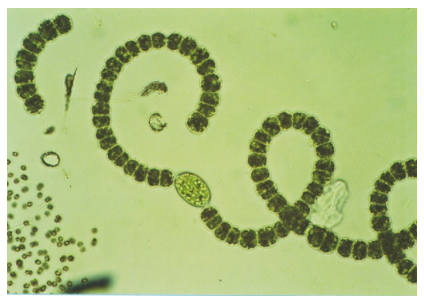

(b) Anabaena

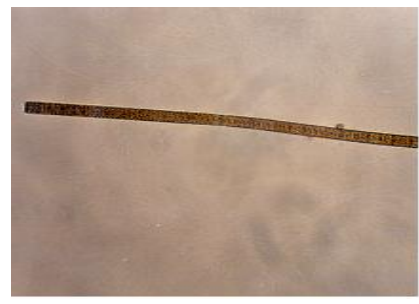

(c) Oscillatoria

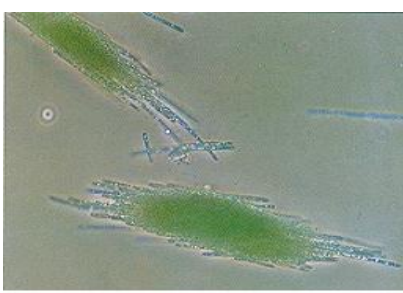

(d) Aphanizomenon

Fig. 5. Microscopic images of blue-green algae (cyanobacteria).

형성하고 세포의 표면에는 점무늬 열이 미약해서 대부분 보이 지 않고 명료하지 않아 거의 없는 것으로 보인다.

\subsection{2. 녹조류}

담수에서 가장 많이 발견되며, 어떤 종은 눈의 표면, 습한 토양, 나무줄기의 녹색 부분, 지의류나 원생동물과의 상호 공 생 등 다양한 환경에서 발견된다.

일반적으로 호소의 담수초기에 많은 종이 발견되고, 여름철 에 활발한 번식이 이루어진다. 남조류나 규조류에 비해 대량 번식하는 우점종은 낮은 편이다. 그러나 대량번식하게 되면 풀냄새, 채소냄새 등의 냄새와 맛을 낸다. Fig.4에 있는 녹조 류의 대표적인 종인 Eudorina는 세포의 직경은 8 10 $\mu \mathrm{m}$ 정 도이며 $16 \sim 32$ 개, 64 개의 세포가 군체를 이루고, 군체는 구형 또는 타원형으로 직경은 $60 \sim 120 \mu \mathrm{m}$ 정도이다. 군체는 한천 질로 둘러싸여 있으며, 또한 여러 군체가 또 다른 한천질에
싸여 있기도 하다. 세포는 2 개의 편모를 가지고 편모를 이용 해서 빠른 회전운동을 하며 유영한다. 규조류가 대발생 시 수 색이 녹색으로 변하며, 비린내를 유발한다.

\subsection{3. 남조류}

남조류는 다량의 점성물질을 세포외부로 분비하며 때때로 이 점성물질은 두꺼운 층 구조를 형성하기도 한다. 몇몇 종의 남조류는 세균과 같이 공기 중의 질소가스를 고정할ㄱ) 수 있 다. 주로 여름철 녹조현상을 일으키는 남조류 중에서 특이한 맛이나 훍 또는 곰팡이 냄새를 유발하기도 하고, 때로 가축이 나 새들에게 유독한 독성물질을 생산하는 종도 있다. 이들이 생산하는 냄새 유발물질은 ${ }^{8}$ 2-MIB 및 Geosmin이 주성분이 며, 독성물질" 로는 간독성을 가진 마이크로시스틴, nodularin 과 신경독성을 가진 anatoxin-a 등이 알려져 있다.

Fig.5에 있는 남조류의 대표적인 종인 Anabaena는 이취미 

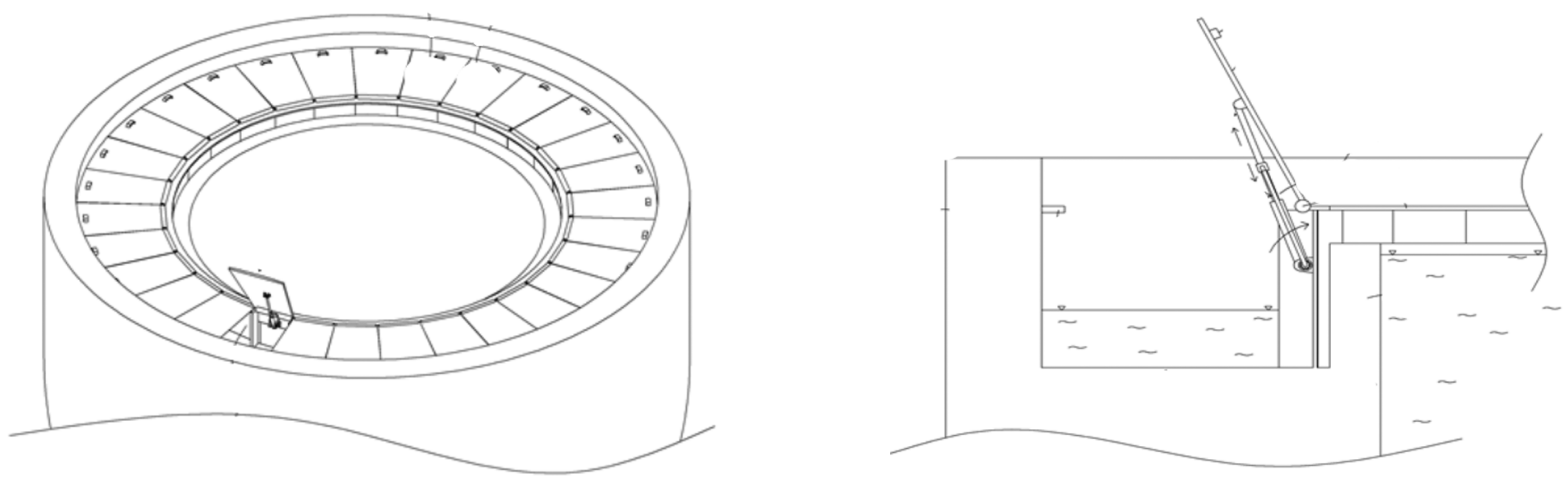

Fig.6. Pictures of installed cover structure of final sedimentation drainage channel.

유발 대표 조류로 세포크기는 5 14 $\mu \mathrm{m}$, 이형세포는 10 16 $\mu \mathrm{m}$ 의 구형이다. 휴먼포자는 초기에는 구형, 나중에는 영양 세포보다 긴 원통모양으로 직경은 7 12 $\mu \mathrm{m}$, 길이는 17 34 $\mu \mathrm{m}$ 정도이다.

\section{3. 결과 및 고찰}

\section{1. 덮개 설치 전·후의 현상학적 변화}

\subsection{1. 덮개 설계}

본 연구에서 사용된 덮개는 Fig.6과 같이 하수처리장 최종 침전지에서 침전된 오니와 상등수로 구분되고 상등수는 웨어 와 배수로를 통해 다음 공정으로 흘러가는데 처리수조의 상단 측면부 수로를 개폐하는 여러 개의 덮개부재와, 배수로의 외 측면부에 구비되는 상기 덮개부재의 지지부재, 수로의 내측면 부에 구비되어 당기 덮개부재가 회전되면서 그 개폐상태를 유지 고정시키는 신축실린더부재로 구성되어 침전지에서 흘 러가는 처리수가 수용되는 수로의 상부면 일부구간이나 전 구간을 용이하게 개폐하여 조류가 발생하는 것을 방지하고, 수로의 청소나 정비를 신속하게 수행하는 하수처리장 덮개 구조체에 관한 것이다.

\subsection{2. 덮개 설치 방법}

덮개를 개폐하려면 최종침전지 좌, 우 대칭에서 우측으로 차례대로 개폐 할 수 있으며, 바람 및 위험성을 방지하기 위해 양쪽에서부터 개폐할 수 있고 중간에 개폐 할 수는 없다. 시작 과 끝은 고리를 이용하여 덮개를 열 수 있게 하였고, 시작점은 잠금장치를 하여 임의로 열 수 없게 하였다. Fig.6의 덮개는 실린더를 이용하여 쉽게 열 수 있게 하였고 웨어 및 배수로 부분을 전부 덮게 하여 조류의 성장단계에서부터 광합성 작용 을 못하게 하였다.

여름철 장마철 태풍으로 바람이 심하게 불 때 신속하게 덮 개 개폐가 가능하며, 양쪽에서 개폐가 가능하고 중간에서 개 폐를 할 수 없으므로 중간부분에서의 배수로 확인은 할 수 없다. 그렇지만 최종침전지 운영상 어려움은 없는 것으로 확
인되었다. 특히 장기적으로 사용함에 따라 덮개의 재질을 STS 304로 제작하여 계절적인 요인(눈, 비, 가스 등)으로부터 미연 에 방지할 수 있게 하였고 덮개 개·폐시 인력으로 조작이 간 편하며 최종침전지 낙하로부터 위험성이 없도록 하였다.

\subsection{3. 덮개 설치 전·후 비교}

옥천하수처리장 최종침전지 웨어 및 배수로의 부착조류의 성장을 예방하기 위하여 웨어 및 배수로 상단에 원형덮개 구 조체를 설치하여 조류의 부착과 성장을 억제시켜 수질개선과 효율적인 침전지 운영을 하고자 하였다. 설치하기 전에 설치 방법, 재료 선택, 위험성 제고, 경제성 검토, 운영 관리 등 여러 가지 현황을 파악하고 설계하기로 했다. 매년 여름철이면 최 종침전지 웨어 및 배수로에 부착조류가 성장하여 외관상 안 좋고, 부착조류를 제거하기 위해 인력으로 부러쉬나 고압호스 를 이용해 부착조류를 제거하고 있는 상황이라 여러 가지 문 제점 해결을 위해 충분히 검토하였다.

Fig.7의 문제점을 해결하기 위해 최종침전지 웨어 및 배수 로에 덮개 장치를 설치하였다. 그 결과 Fig.8과 같이 최종침전 지 웨어 및 배수로에 부착조류 발생이 현저하게 감소되었다. 그리고 재료를 스테인리스로 사용하여 덮개 장치가 녹이 슬지 않게 하였고 견학시 미관 상태 청결로 침전지 운영관리에 효 과적으로 관리되고 있다. 덮개 장치가 견고하여 계절의 영향 (비, 바람 등)으로부터 안전하며, 운영 관리시 작업자의 위험 성으로부터 안전하게 보호할 수 있었다.

\section{2. 덮개 설치 전·후 부착조류 및 조류 종별 비교 분석 결과}

\subsection{1. 덮개 설치 전·후 부착조류 비교}

최종침전지 배수로 부착조류의 부착상태를 확인하기 위해 덮개 설치 전·후를 비교하였다. 덮개 설치 전 광합성 작용하 에서 자연중에 부착조류의 성장과정을 지켜보면서 확인하였 고, 부착 후 배수로 덮개 설치 후 14 일이 지난 후에 개방하여 비교하였다. Fig.9는 최종침전지 웨어 및 배수로를 비교한 결 과 덮개 설치 전 최종침전지 웨어 및 배수로는 부착조류가 많이 발생한 것을 확인할 수 있었고, 덮개 설치 후 최종침전지 

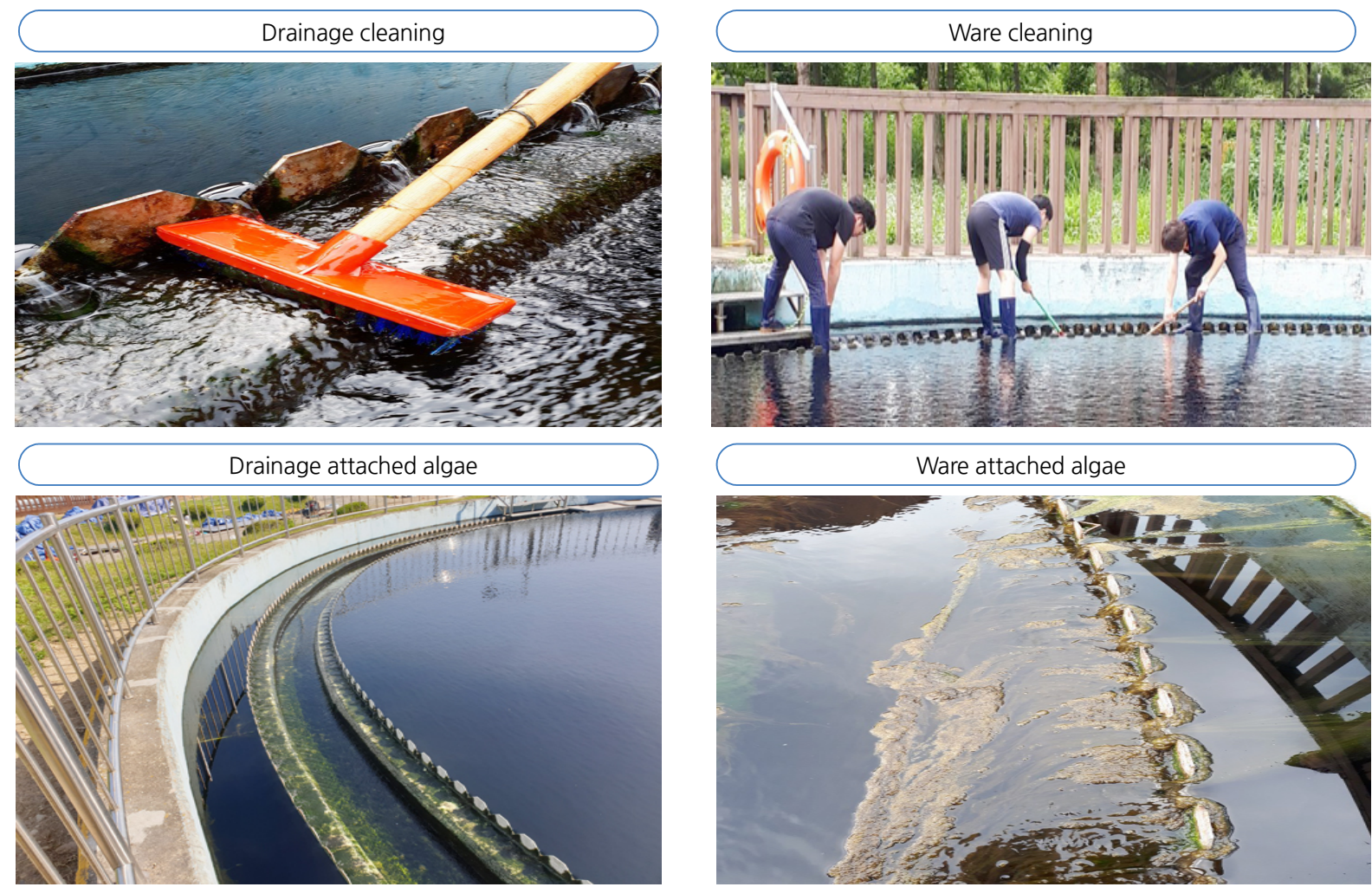

Fig.7. Picture of cleaning periphytic algae at sedimentation basin.
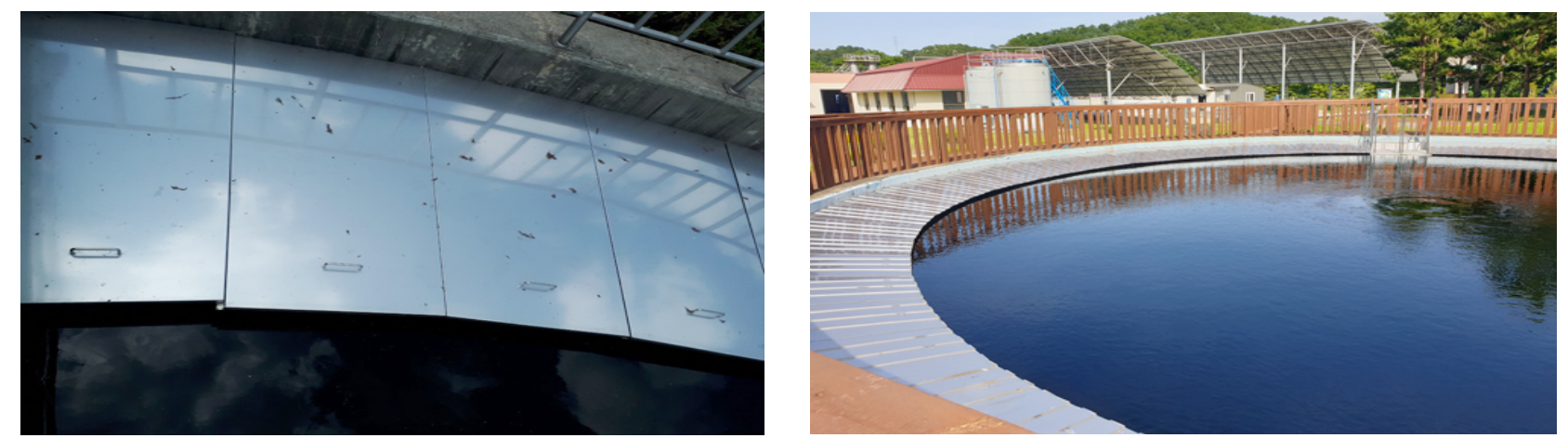

Fig. 8. Pictures of installed cover structure of final sedimentation drainage channel.

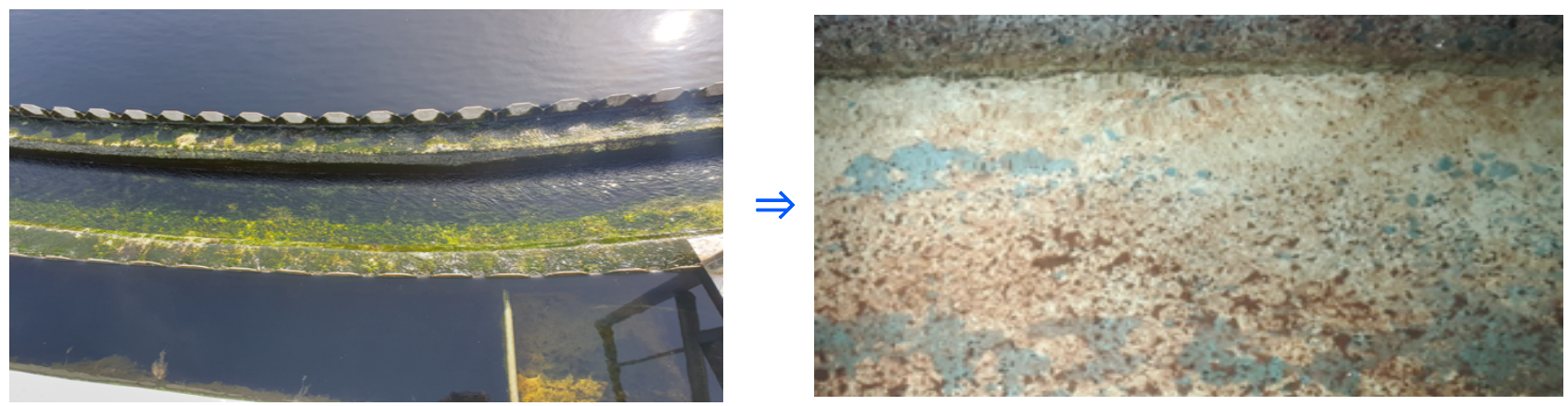

Fig. 9. Pictures of before installation of drainage channel cover and after.

웨어 및 배수로는 부착조류가 발생하지 않아 육안으로 확실히 확인할 수 있었다.
웨어 및 배수로 부착조류의 조류 종은 규조류로 구성되어 있으며 덮개 설치 유무에 관계없이 조류 종은 일정했다. 부착 

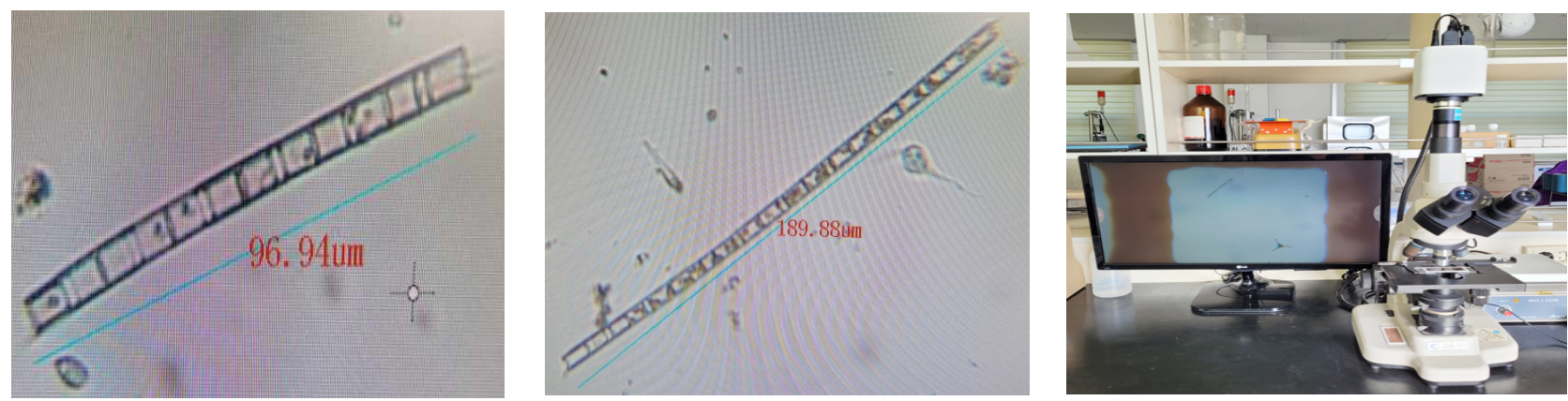

Fig. 10. Microscopic images of periphytic algae species in sewage treatment plant.
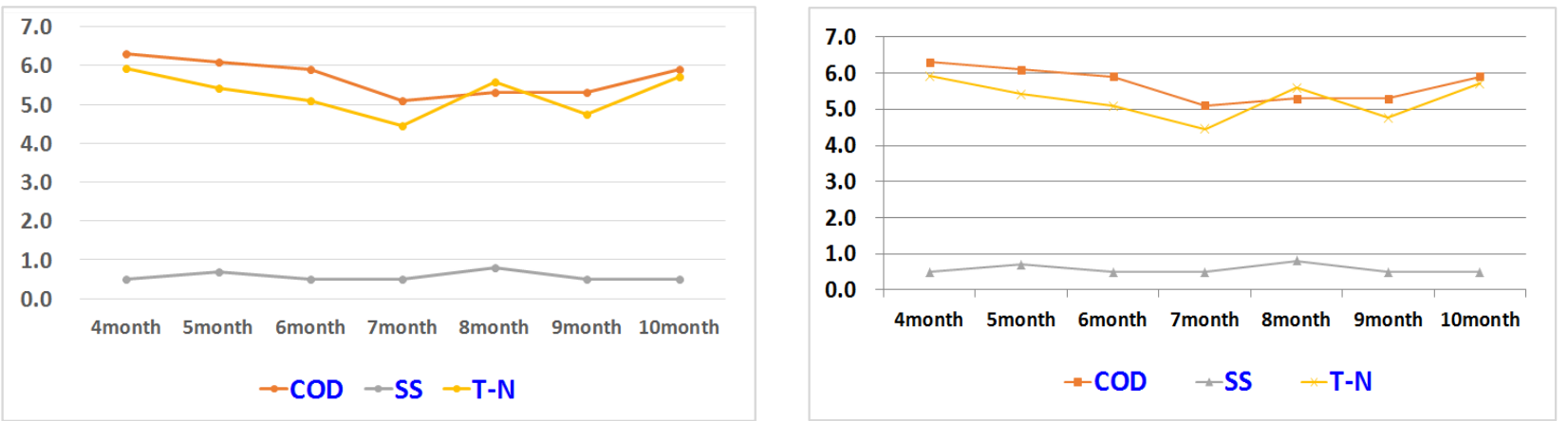

Fig. 11. Water quality of final sedimentation tan before and after cover device installation.

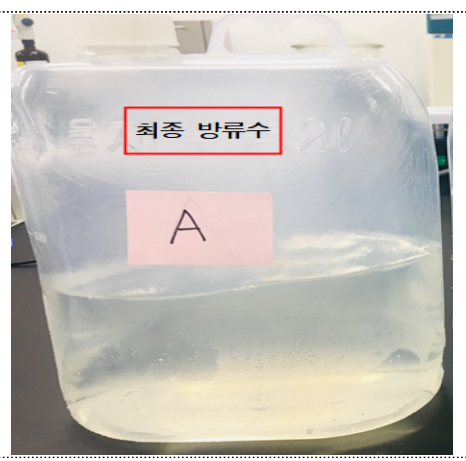

(a) Effluence not included with attached algae

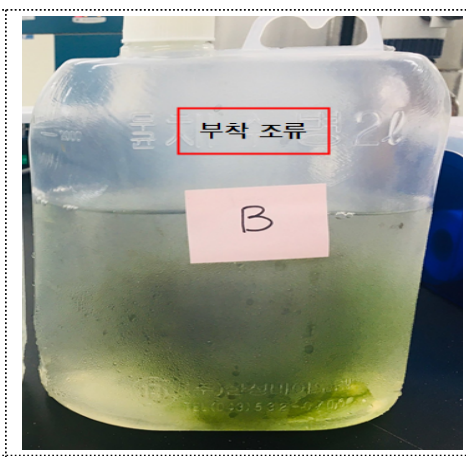

(b) Effluence included with attached algae

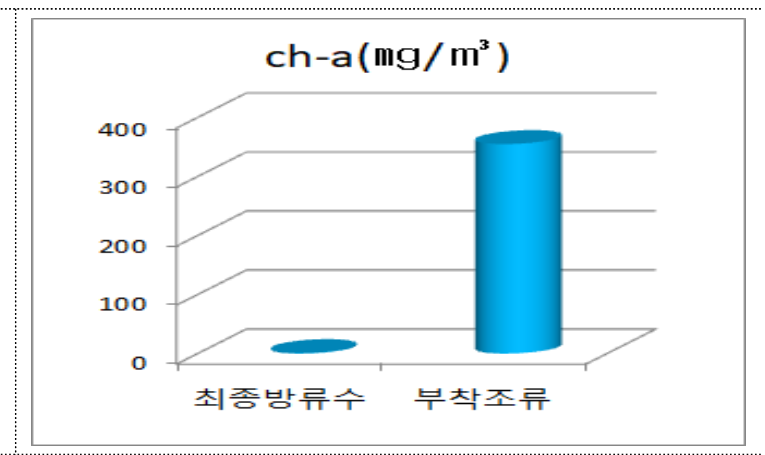

(c) Effluence included with attached algae or not included ch-a concentration

Fig. 12. Chlorophyll-a analysis results of final effluent and periphytic algae.

조류 발생은 배수로의 재질 및 계절에 따른 영향뿐만 아니라 부착성이 강한 조류가 군집을 형성한 후 유출수에 함유되어 있는 미생물 종 등이 2차적으로 부착 성장하여 군집을 형성 하였을 것으로 사료된다. ${ }^{10)}$

\subsection{2. 조류 종별 비교 분석 결과}

Fig.10는 옥천하수처리장 실험실에서 최종침전지 웨어 및 배수로에 부착된 부착조류를 현미경(배율 200배)으로 관찰한 결과 $95 \%$ 가 규조류인 Melosira로 관찰되었다. 배수로에 부착 된 부착조류를 광학현미경으로 관찰한 것이며, 현미경 관찰 사진과 국립환경연구원의 조류 도감과 비교하여 종을 추정하 였다. Melosira의 길이는 160 190 $\mu \mathrm{m}$ 정도의 원통형 세포이
며 조밀하게 직선상으로 연결되어 군체를 형성하고 있다. ${ }^{11)}$ 다세포 형태의 조류는 다양하고 복잡한 형태를 하고 있으며, 세포와 세포가 붙어서 세포들이 단순하게 모여 집락을 형성하 며 존재하는 것들과 다른 기능을 가진 세포 형태들이 모여 있는 것도 있다. ${ }^{12)}$

\section{3. 덮개 설치 전·후 처리수 수질 변화}

Fig. 11은 최종침전지에 덮개를 설치 전·후 수질을 분석하 였다. 분석 결과 COD, T-N, T-P의 방류수 수질은 변화가 없는 것으로 확인되었으며, 방류수 SS 농도는 덮개 장치 설치 후 약 $15 \%$ 향상되었다. 
Table 1. Reviewing the cost of cleaning labor and the cost of installing cover devices.

\begin{tabular}{|c|c|c|c|}
\hline & Division & Content & Expense \\
\hline \multirow{4}{*}{ Clean-up costs } & Labor costs & 150,000 won/day & \multirow{4}{*}{$10,800,000$} \\
\hline & Work period & 12 month & \\
\hline & Number of people & Three people & \\
\hline & Number of work & 2 times & \\
\hline Installation expense & Installation details & $\begin{array}{l}\text { Material : Angle, steel plate } \\
\text { Installation cost }\end{array}$ & $34,000,000$ \\
\hline
\end{tabular}

\section{4. 덮개 설치 전·후 클로로필- $a$ 농도 분석}

Fig. 12는 부착조류가 포함된 최종침전지 시료와 부착조류 가 포함되지 않은 시료의 ch-a ${ }^{13)}$ 농도를 실험실에서 UV로 측 정한 결과 부착조류가 포함된 시료는 $354.5 \mathrm{ppm}$, 부착조류가 포함되지 않은 시료의 ch-a 농도는 $0.8 \mathrm{ppm}$ 으로 나타났다. 실 험 결과 부착조류가 포함되지 않으면 방류수 수질에 영향이 없으며, 부착조류가 많이 발생하면 방류수 수질에 영향이 있 다는 사실을 알 수 있었다.

\section{5. 경제성 검토}

부착조류의 발생 저감을 위해 설치 후 덮개 장치는 수질 향 상 및 외관상 이미지 개선에 영향을 주었다. Table 1과 같이 설치 전 침전지 웨어 및 수로의 청소 인건비 $(12$ 개월 $\times 2$ 회/월 $\times 3$ 인 $\times 150$ 천원 $/$ 인 $=10,800$ 천원 $)$ 가 절약되었으며, 작업자의 위험성 해소 및 최종침전지 운영 관리에 효과적으로 관리되고 있다.

덮개 설치 비용(침전지 둘레 길이 $34 \mathrm{~m}$, 재질 STS 304, 34,000 천원)을 경제성 비교 검토한 결과 인건비 대비하여 회수기간이 2.6년으로 나타났다. 설치 재료에 따라 영향도 있지만, 그보다 더 중요한 것은 덮개를 설치하여 광합성작용을 차단하는 것이 부착조류의 발생을 억제하는 최선의 방법이라는 결과를 도출 하였다.

앞으로 하수저리장 최종침전지 및 정수장까지 확대 설치하 여 하절기 조류 발생 저감에 효과가 있을 것으로 기대된다.

\section{4. 결론}

1) 최종침전지 웨어 및 배수로 부착조류는 규조류인 Melosira가 95\%, 기타 남조류 및 녹조류가 5\%로 분포되었다.

2) 침전지 구조물에서는 4 월 10 월 달까지 부착조류가 관 찰되고 청소 후 7일 후부터 부착조류가 점진적으로 증가되었 으며, 부착조류제거 청소 인건비는 년간 10,800 천원(하절기 주 2회, 동절기 주 1회) 지출되었다.

3) 웨어 및 배수로 재질을 스테인리스, 에폭시, 알루미늄으 로 하면 부착조류의 발생 시기는 늦출 수 있으나 완전히 억제 시키지는 못하였으며 덮개 설치 비용은 34,000 천원으로 경제 성 검토한 결과 회수기간 2.6년으로 설치하는 것이 효율적이
란 결론을 얻었다.

4) 최종침전지 방류수 및 부착조류의 클로로필-a 농도를 수 질검사 한 결과 최종침전지 방류수 $0.8 \mathrm{ppm}$, 부착조류 354.5 $\mathrm{ppm}$ 으로 나타났으며, 덮개를 설치 후 처리효율이 $99.8 \%$ 로 나 타났다.

5) 배수로 상단에 덮개 구조체를 설치하여 조류의 부착과 성장을 억제시켜 최종침전지 SS 처리효율 $15 \%$ 향상되어 효 율적인 침전지 운영을 할 수 있었다.

\section{References}

1. H.-J. Son, J.-M. Jeong, S.-Gu Kim, S.-H. Jang, Using $\mathrm{CuSO}_{4}$ for preventing algae attachment on the sedimentation basin of industrial water treatment plant, Journal of Korean Society of Environmental Engineers, 780-785(2010).

2. H. S. Yoo, B. R. Lim, G. H. Ahn, Analysis of the seasonal change in attached algae and microbial community structure in sediment basin trough of water treatment plant by using quinone profile and pcr-dgge, J. Korean Soc. Water Wastewater., 20(3), 461-467(2006).

3. G.-H. Ahn, B.-R. Im, D. -Y. Jeon, H.-S. Yoo, Y.-J. Park, A study on the control method of attached algae in the sedimentary drainage in the water purification plant, in Proceedings of the 2004 Joint Fall Conference, Korean Water and Sewer Association, Korean Society for Water Environment(2004).

4. K.-M. Kim, H.-H. Oh, J.-W. Park, J.-J. Choi, J.-H. Ahn, Effect of TiCl4 coagulation on algae remove, J. Korean Soc. Environ. Eng., 41(6), 356-360(2019).

5. D. Y. Jeon, B. R. Lim, H. S. Yoo, J. W. Cho, J. H. Hwang, K. H. Ahn, research papers: improvement of drainage material for attached algae growth control in sedimentation basin, J. Korean Soc. Water Wastewater., 193-199(2005).

6. J. Jeong, C. M. Park, J. M. Jung, J. Y. Kim, B. K. Park, N. S. Han, M. D. Kim, Freshwater algae collection by water system of the national water source, Waterworks Research Institutions Council, Seoul, Korea(2012).

7. M.-J. Lee, J.-C. Joo, G.-Y. Kim, C.-H. Ahn, S. R. M. Lee, Evaluation on growth inhibition effect of harmful blue green algae using $\mathrm{Tio}_{2}$-embedded expanded polystyrene (tieps) balls: river/reservoir mesocosms, J. Korean Soc. Environ. Eng., 41(11), 647-656(2019). 
8. Y.-U. Kim, H.-J. Son, M.-H. Yu, C.-S. Lee, A study on relation of attached algae and odor's cause in sedimentation basin of water treatment plant, J. Korean Soc. Environ. Eng., 887-894(2000).

9. Y.-E. Moon, H.-S. Kim, Spatiotemporal distribution of algae and characteristics of algal abundance in lake Okjung, Korea, J. Korean Soc. Environ. Eng., 41(10), 554-571(2019).

10. B. R. Lim, G. H. Ahn, G. E. Song, Y. J. Park, D. Y. Jeon, Analysis of attached algae and microbial community structure in sedimentation basin of water and wastewater treatment plant, J. Korean Soc. Water Wastewater, 61-67 (2005).

11. National institute of environment research, Phytoplankton of Lake Paldang, National institute of environment research, Incheon, Korea(2014).

12. Waterworks Research Institutions Council, Nationwide freshwater algae houses by water system, Waterworks Research Institutions Council, Seoul, Korea. pp. 14-20(2012).

13. K.-H. Oh, D.-H. Jeong, S.-Y. Yang, T.-W. Jeon, Y.-C. Cho, Effects of submerged aerator on the growth of algae in Daechung Reservoir, J. Korean Soc. Environ. Eng., 35(4), 268-275(2013).

\section{Declaration of Competing Interest}

The authors declare that they have no known competing financial interests or personal relationships that could have appeared to influence the work reported in this paper.

\section{Authors and Contribution Statement}

\section{Sun Whae Lim}

Department of Environment Engineering, Hanbat National University, Ph. D. Student, ORCiD(D) 0000-0001-9212-1843: Data analysis, Conceptualization, Writing - original draft.

\section{Cheol Hyeon Jang}

Department of Environment Engineering, Hanbat National University, Professor, ORCID (ㄷ) 0000-0003-0422-774X: Validation, Methodology, Project administration.

\section{Byong Ro Ryu}

Department of Environment Engineering, Hanbat National University, Professor, ORCID (0) 0000-0003-0592-5566: Validation, Methodology, Project administration.

\section{Yong Soon Lee}

Department of Environmental Engineering, Daejeon University, $\mathrm{Ph}$. D. Student, ORCID (10 0000-0002-3832-4161: Conceptualization, Writing - original draft, Writing - review and editing. 